\title{
Application of the Hybrid X-Ray Instrument for Measurement of Thorium-Plutonium Mixed Solutions
}

\author{
S. -T. Hsue \\ H. Eberle*
}

\section{DISCLAIMER}

\begin{abstract}
This report was prepared as an account of wot
Government. Neither the Un account of work sponsored

employees, makes any the United States Government bility for the accurakes warranty, express or implied nor any agency thereof, nor any States process disclosed, ory, completeness, or usefulied, or assumes any legal liability any of their ence herein to ar represents that its use would of any information liability or responsj. manufacturer, any specific commercial use would not infringe privately ownetus, product, or mendation, or or otherwise does not necessarily process, or service by owned rights. Referand opinions of avoring by the United States constitute or imply its ename, tradernark, United States of authors expressed herein Government or any agendorsemeni, recomStates Government or any agency do not necessarily state or thereof. Tte views
\end{abstract}




\section{CONTENTS}

ABSTRACT . . . . . . . . . . . . . . . . . 1

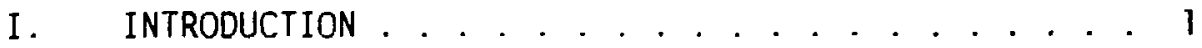

II. EXPERIMENTAL SETUP ................. 2

A. Hybrid Instrument ........... 2

B. Standards ............. 5

III. RESULTS AND DISCUSSION . . . . . . . . . . 5

A. Optimization of the Hybrid Instrument . . . 5

B. Performance Evaluation......... 10

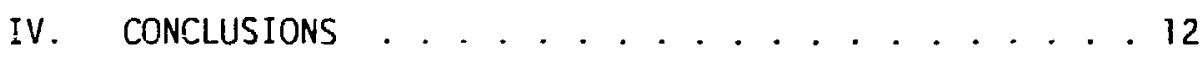

REFERENCES .................. 13 
APPLICATION OF THE HYBRID X-RAY INSTRUMENT

FOR MEASUREMENT OF THORILIM-PLUTONIUM MIXED SOLUTIONS

by

S. $-T$. Hsue and H. Eberle

\begin{abstract}
The hybrid K-edge densitometry/K-x-ray fluorescence instrument constructed by Kernforschungszentrum Karlsruhe, Federal Republic of Germany, is used to measure Th/Pu mixed solutions. We found that the optimal accelerating voltage for measuring these mixed solutions is $130 \mathrm{kV}$. At optimum operating conditions, the detection limit for thorium is about $25 \mathrm{mg} / \mathrm{l}$. The minimum Th/Pu ratio that can be assayed by the instrument is about $1 / 1000$.
\end{abstract}

\title{
I. INTRODUCTION
}

The major aqueous process used to recover and purify plutonium at the Los Alamos Plutonium Facility is anion exchange in nitric acid. A weakness of this process is its inability to cleanly separate the thorium impurity from plutonium, which results in a continuous recycling and builusp of the thorium. Alternative processes are availabie to separate thorium; however, these tedious and time-consuming options should be used only when the level of thorium impurity clearly justifies them. An assay method is needed to determine the trace amounts of thorium in the plutonium product solutions. Nondestructive assay is preferable because chemical determination of trace amounts of thorium is difficult, as well as time consuming. We have performed an experiment to find a nondestructive technique to assay both thorium and plutonium concentrations in such solutions. 
The hybrid K-edge densitometry/K-X-ray fluorescence (XRF) instrument constructed by Kernforschungszentrum Karlsruhe $(K f K)^{1-3}$ has demonstrated that it can assay plutonium in uranium-plutonium mixed solutions (plutonium being the minor special-nuclear-material component) at a Pu/U ratio of approximately 0.01. In that application of the hybrid instrument, K-edge densitometry is used to determine the uranium concentration and the XRF technique is used to determine the Pu/U weight ratio. For our application, a technique is needed that can determine Th/Pu weight ratios of approximately 0.001 (or even lower) with reasonable precision and accuracy. Our investigation is intended as a study of the feasibility of tailoring the hybrid instrument to the assay of plutonium-thorium mixed solutions at small Th/Pu ratios.

\section{EXPERIMENTAL SETUP}

\section{A. Hybrid Instrument}

Figure 1 shows the layout of the hybrid instrument. For simultaneous K-edge densitometry and XRF, a second germanium detector is added to the basic K-edge densitometer setup. The additional detector (used for XRF) is located at the largest possible backward angle relative to the direction of the primary $x$-ray beam. In this geometry, the primary $x$ rays, which to a large extent are inelastically scattered from the solution sample, are energetically shifted below an energy of about $100 \mathrm{keV}$, provided the $x$-ray tube is operated at voltages not larger than about $160 \mathrm{kV}$.

The instrument uses a tandem sample consisting of a glass cuvette with an accurately known path length $(2 \mathrm{~cm})$ for K-edge densitometry and a thin-walled 1-cm-diam polyethylene caisule for XRF. Use of a separate cell for XRF optimizes the signal-to-background ratio for the more critical fluorescence measurement. Both sample cells are located at an $8-\mathrm{cm}$ distance from the focal spot of the $x$-ray tube. They are irradiated by two collimated $x$-ray beams and are filtered by $1-m m$ cadmium for the XRF analysis and by $15 \mathrm{~mm}$ of stainless steel for K-edge densitometry. The straight-through $x$-ray beam for K-edge densitometry is highly collimated through a $12-\mathrm{cm}-10 \mathrm{ng}, 0.08-\mathrm{cm}-\mathrm{diam}$ tungsten collimator located between the sample and detector. Figure 2 show's the tailored $x$-ray continuum thorium-plutonium spectrum in the K-edge densitometry portion of the 


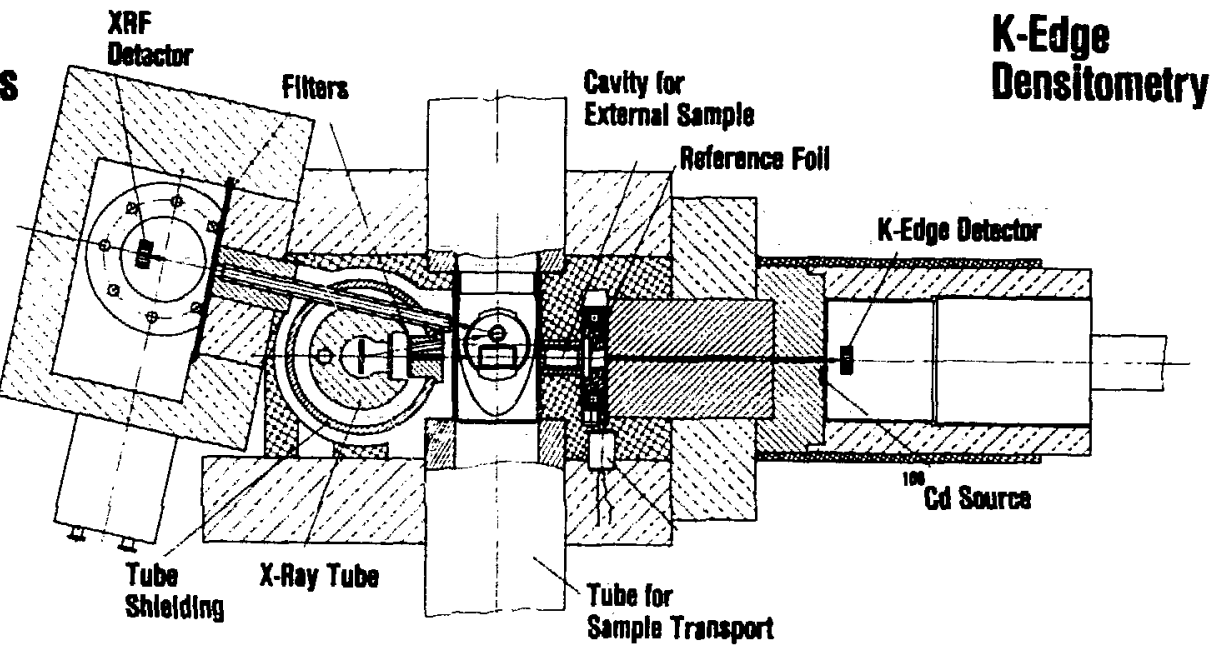

Fig. 1. Cross-sectional plan of the hybrid instrument.

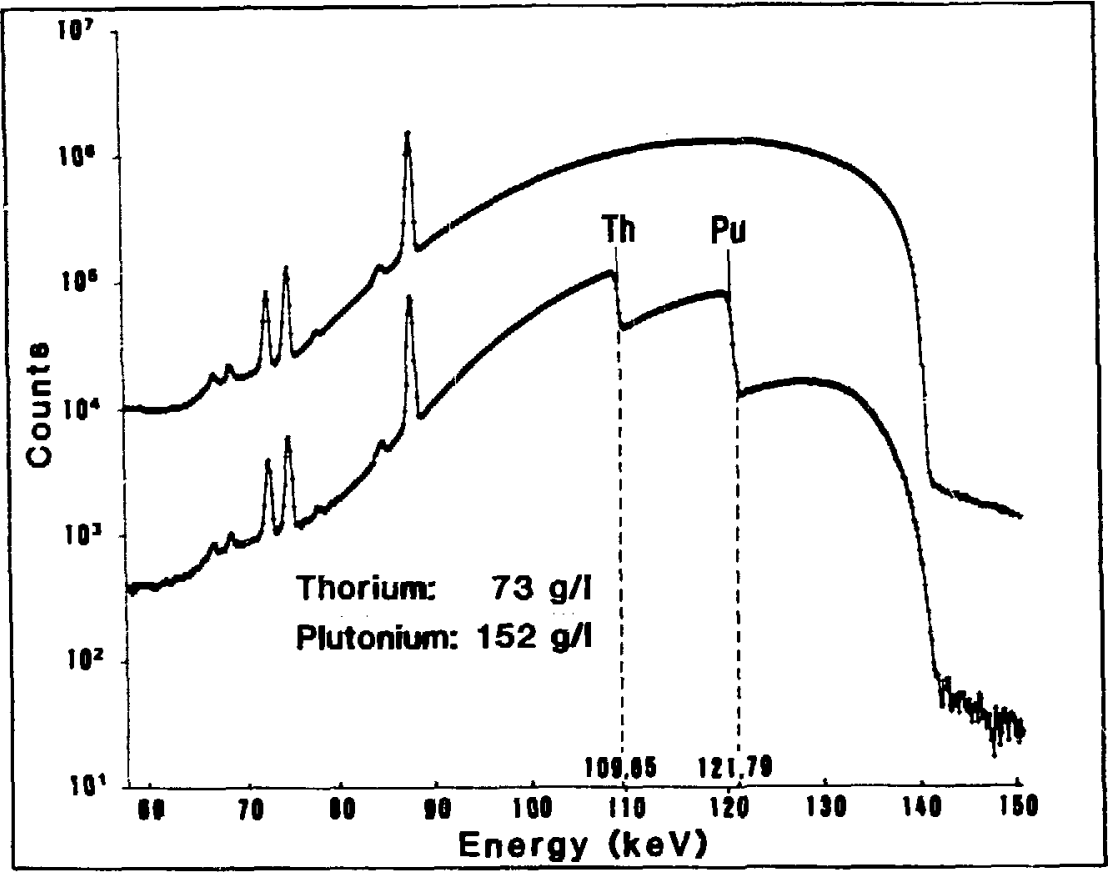

Fig. 2. Tailored $x$-ray continuum spectrum (top) from the generator and the transmission spectrum (bottom) through a solution containing $73 \mathrm{~g}$ Th/ $\mathrm{l}$ and $152 \mathrm{~g} \mathrm{Pu} / \mathrm{l}$. 
system as well as the $x$-ray transmission spectrum through a mixed solution. A uranium metal foil mounted in a motor-driven frame can be inserted iitu the beam path for measurement control purposes. The XRF detector, located at a backward angle of $157^{\circ}$ with respect to the primary $x$-ray beam directed toward the XRF cell, views the sample through a 14-cm-long, 0.6-cm-diam tungsten col1 imator.

The experimental setup (Fig. 3) is installed behind a hot cell. It is built around a stainless steel tube used for sample transport; the tube extends through the biological shield into the interior of the hot cell.

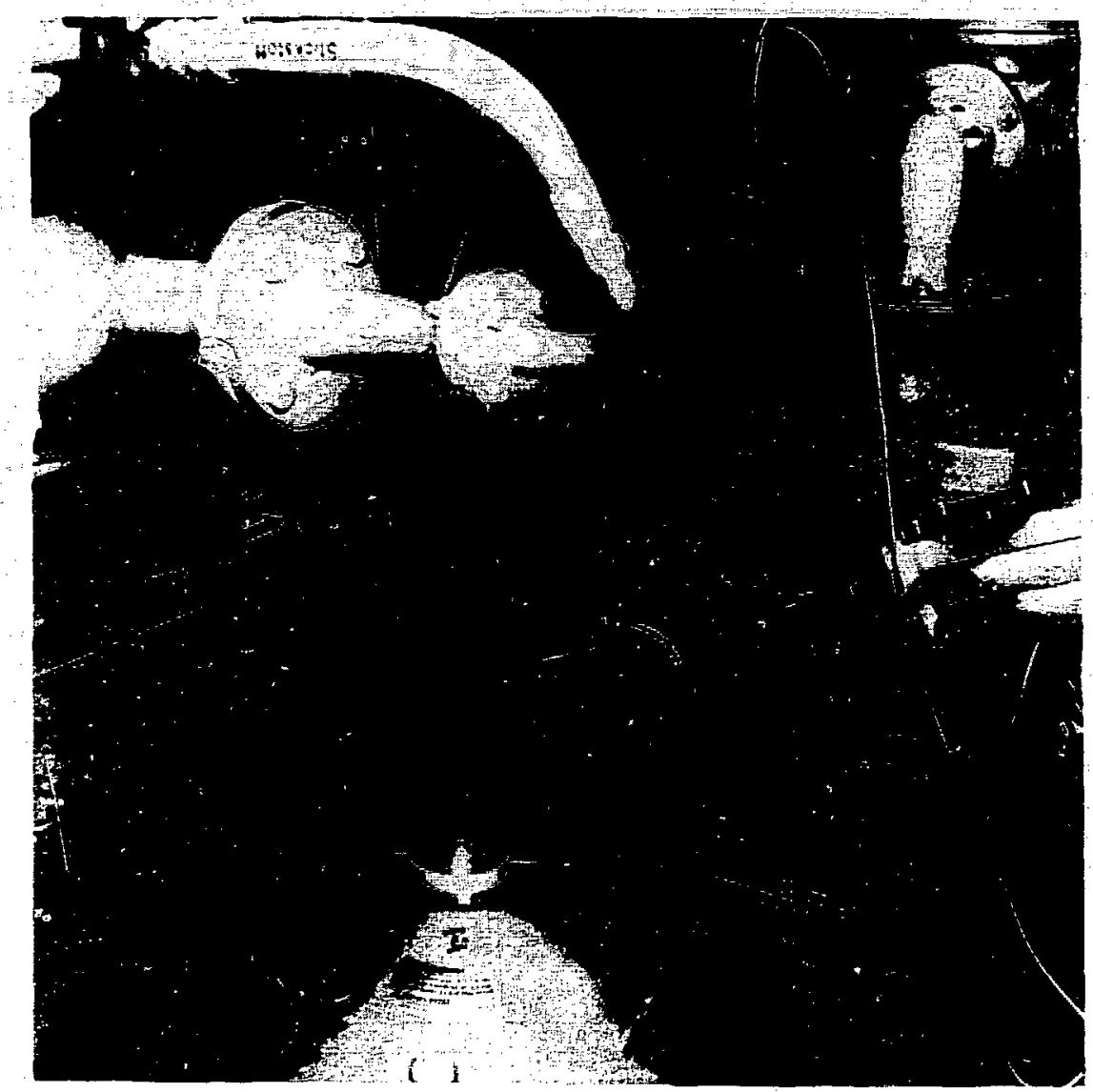

Fig. 3. Photograph of the hybrid instrument located behind a hot cell. 
B. Standards

A set of standards was prepared for the experiment, with Pu/Th ratios ranging from 50 to 1000 . The plutonium is obtained from the product solutions of a light-water-reactor reprocessing plant several months after separation. Table I shows the isotopic distribution of the plutonium at the time of the experiment. The thorium is obtained from a stock solution used to prepare thorium standards. The concentrations of the standards in $3 \underline{M}$ to $5 \underline{M}$ nitric acid matrixes are summarized in Table II.

\section{RESULTS AND DISCUSSION}

\section{A. Optimization of the Hybrid Instrument}

The hybrid instrument is optimized for the assay of thorium-plutonium mixed solutions primarily by optimizing the XRF measurement used for determining the minor component. The bottom curve in Fig. 4 shows the filtered $x$-ray continuum at $150 \mathrm{kV}$ accelerating voltage, the voltage usually employed for analysis of uranium-plutonium mixed solutions. The relative position of the absorption-edge energies indicates that thorium atoms can be preferentially excited relative to plutonium atoms when the accelerating voltage is lowered to

\section{TABLE I}

PLUTONIUM ISOTOPIC DISTRIBUTION

(August 5, 1986)

\begin{tabular}{|c|c|c|}
\hline I sotope & Wt\% & $\begin{array}{c}\text { Precision } \\
(\%) \\
\end{array}$ \\
\hline${ }^{238} \mathrm{pu}_{\mathrm{u}}$ & 1.95 & 1.43 \\
\hline 23 & 55.59 & 0.68 \\
\hline 24 & 25.19 & 1.14 \\
\hline${ }^{241} \mathrm{Pu}$ & 11.50 & 1.28 \\
\hline${ }^{242} \mathrm{Pu}$ & 5.77 & 10.0 \\
\hline $241 \mathrm{Am}$ & $2486 p p m$ & 1.22 \\
\hline
\end{tabular}


TABLE II

PLUTONIUM AND THORIUM CONTENT OF STANDARDS

\begin{tabular}{|c|c|c|c|}
\hline $\begin{array}{l}\text { Standard } \\
\text { No. }\end{array}$ & $\begin{array}{c}\text { Plutonium } \\
\text { Concentration } \\
(\mathrm{g} / \mathrm{l}) \\
\end{array}$ & $\begin{array}{c}\text { Thorium } \\
\text { Concentration } \\
(\mathrm{g} / \mathrm{l}) \\
\end{array}$ & $\begin{array}{l}\text { Pu/Th } \\
\text { Ratio } \\
\end{array}$ \\
\hline 4 & 100.0 & 0.5 & 200 \\
\hline 5 & 100.0 & 2.0 & 50 \\
\hline 6 & 100.0 & 0.1 & 1000 \\
\hline 7 & 220.0 & 0.23 & 956 \\
\hline 8 & 220.0 & 1.2 & 183 \\
\hline 9 & 50.0 & 1.0 & 50 \\
\hline 10 & 50.0 & 0.25 & 200 \\
\hline 11 & 50.0 & 0.05 & 1000 \\
\hline
\end{tabular}

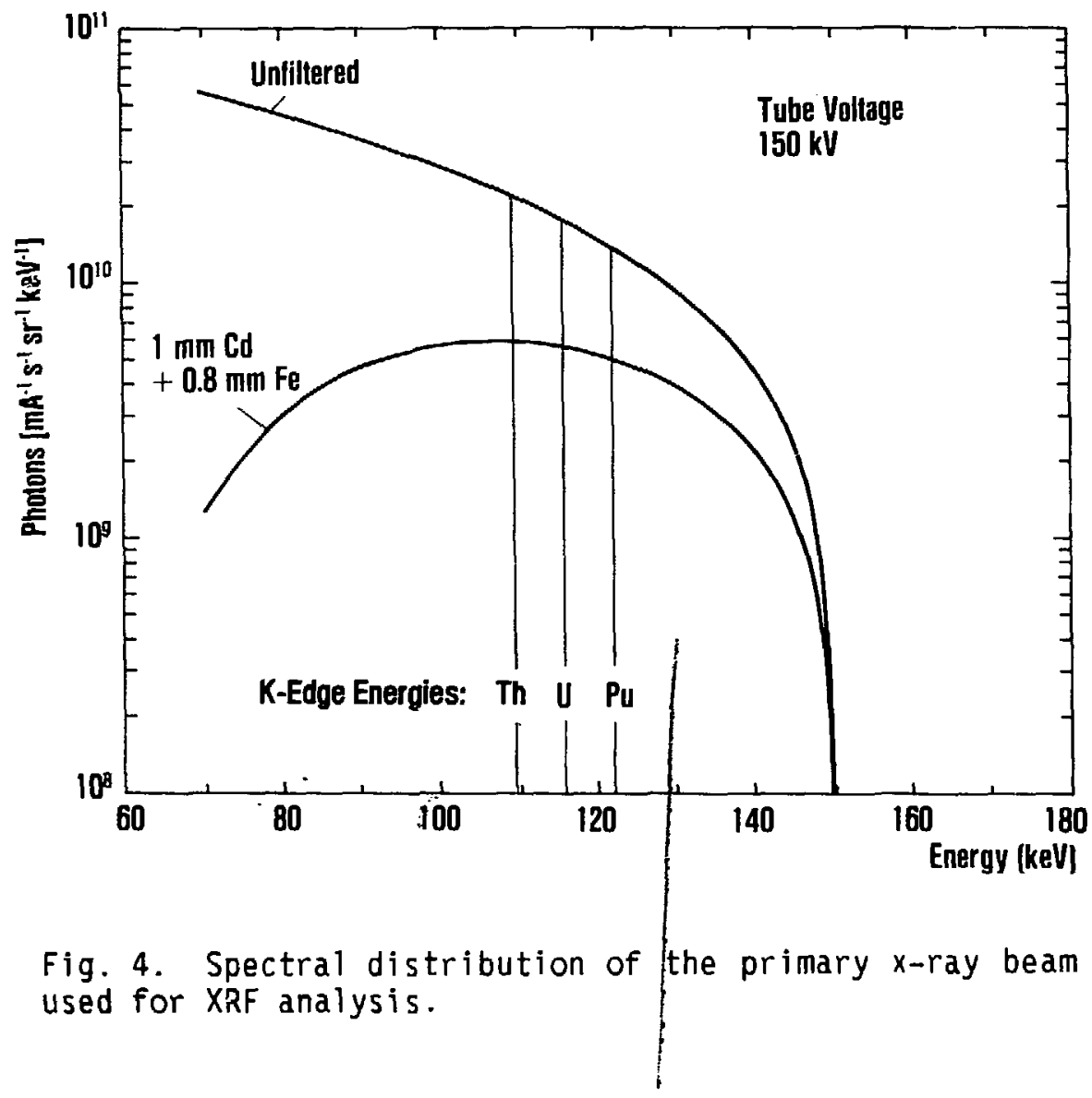


values not far above the plutonium absorption-edge energy. The enhancement of the $k \times$ rays of thorium relative to those of plutonium is shown in $F i g .5, a$ plot of XRF spectra taken at 125 and $130 \mathrm{kV}$. The figure also shows that as the accelerating voltage is reduced, the relatively broad backscattered peak moves down in energy, thereby improving the peak-to-background ratio of the thorium $\mathrm{K}_{\alpha}$ line. However, the total net counting rate of the thorium $\mathrm{K}_{1}$ line is also reduced with voltage reduction so that the precision of determining the Th/Pu ratio deteriorates.

To determine the optimum operating voltage more quantitatively, data were collected at 125-, 130-, 140-, and 150-kV accelerating voltages for sample number 9 . Since the thorium $k_{\alpha} \times$ rays reside on the sloping background of the backscattered primary $x$ rays, the method used for net peak-area determination becomes very important, particularly at low thorium concentrations with correspondingly poor peak-to-background ratios. We have adopted the filtering

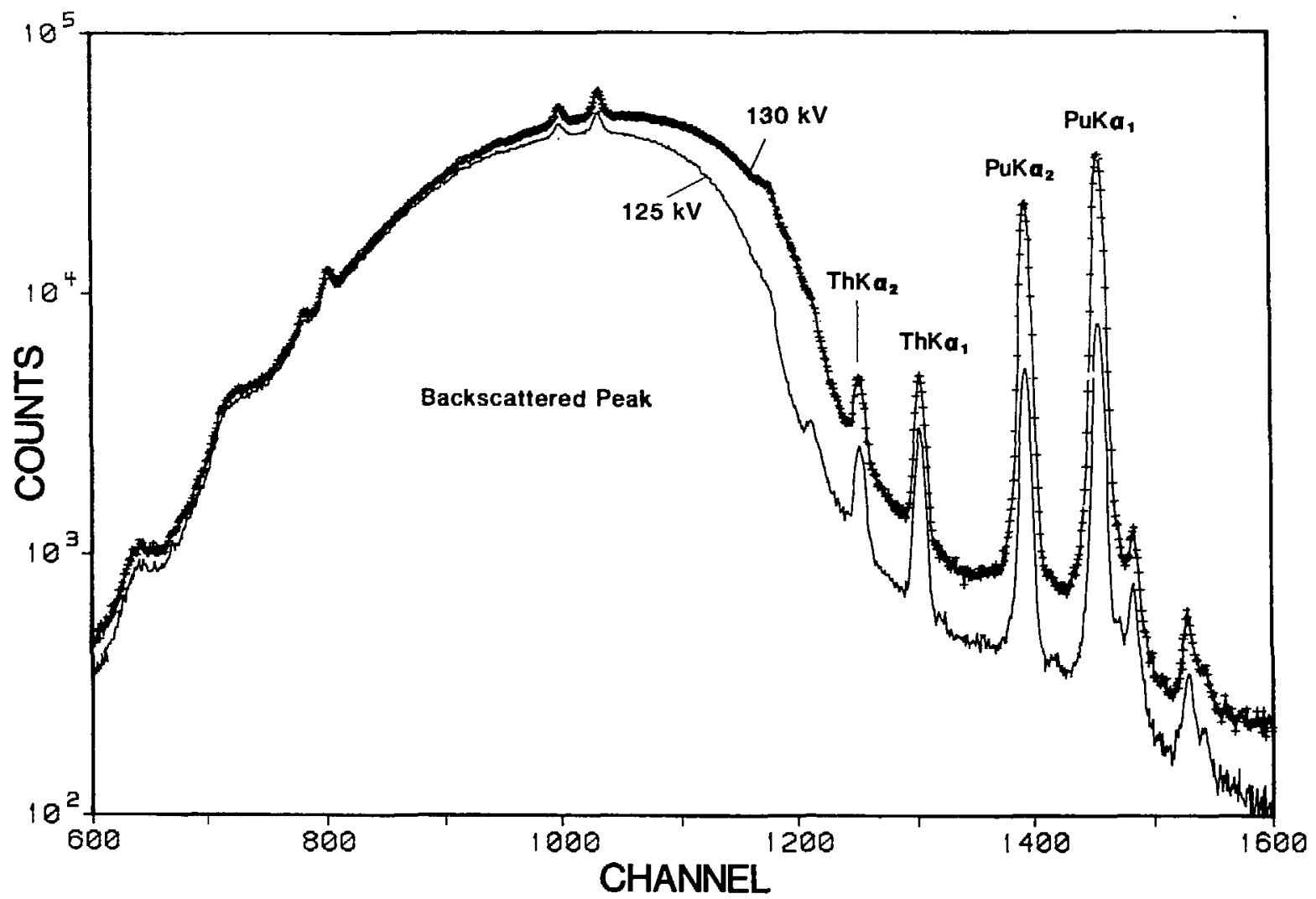

Fig. 5. XRF spectra from 125- and 130-kV accelerating voltages. 
method proposed by Kawarasaki ${ }^{4}$ for removal of the background. The bottom curve in Fig. 6 shows an example of a filtered XRF spectrum after background removal.

Figure 7 shows the peak-to-background $(P / B)$ ratio for the thorium $K \alpha_{1}$ peak as a function of different accelerating voltages. This $P / B$ ratio increases with decreasing voltages, mainly reflecting the lowering of the energy of the backscattered peak.

Table III shows the precision of 1000-s determination of the Th/Pu ratio. Based on the measurement precision, the best accalerating voltage for the XRF measurement is $130 \mathrm{kV}$. Also shown in Table III are the Th/Pu ratios. From 140 to $125 \mathrm{kV}$, the Th/Pu ratio is enhanced by approximately a factor of 6 .

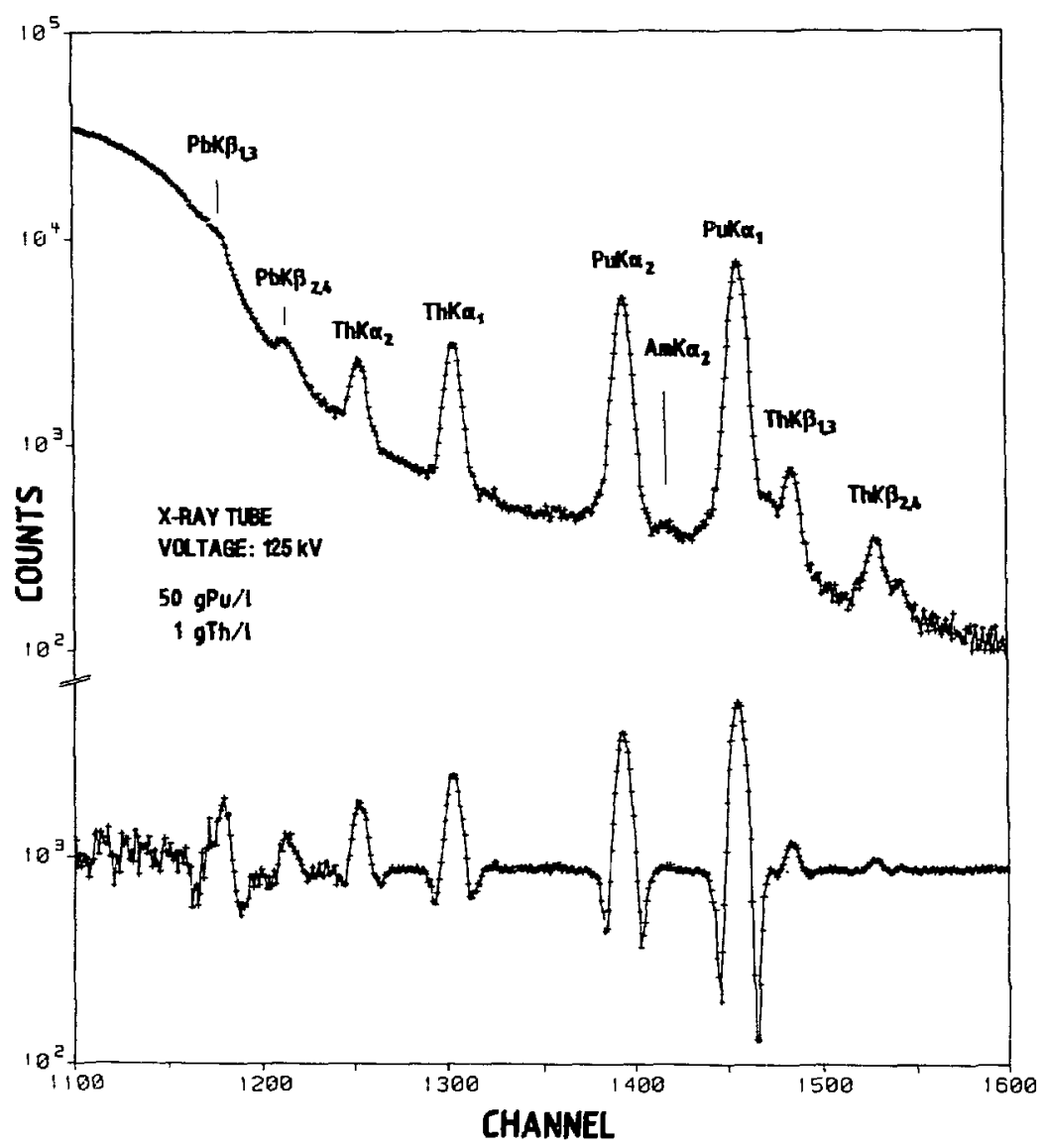

Fig. 6. XRF spectrum before (top) and after (bottom) using the filtering method of Ref. 4 to remove the background. 


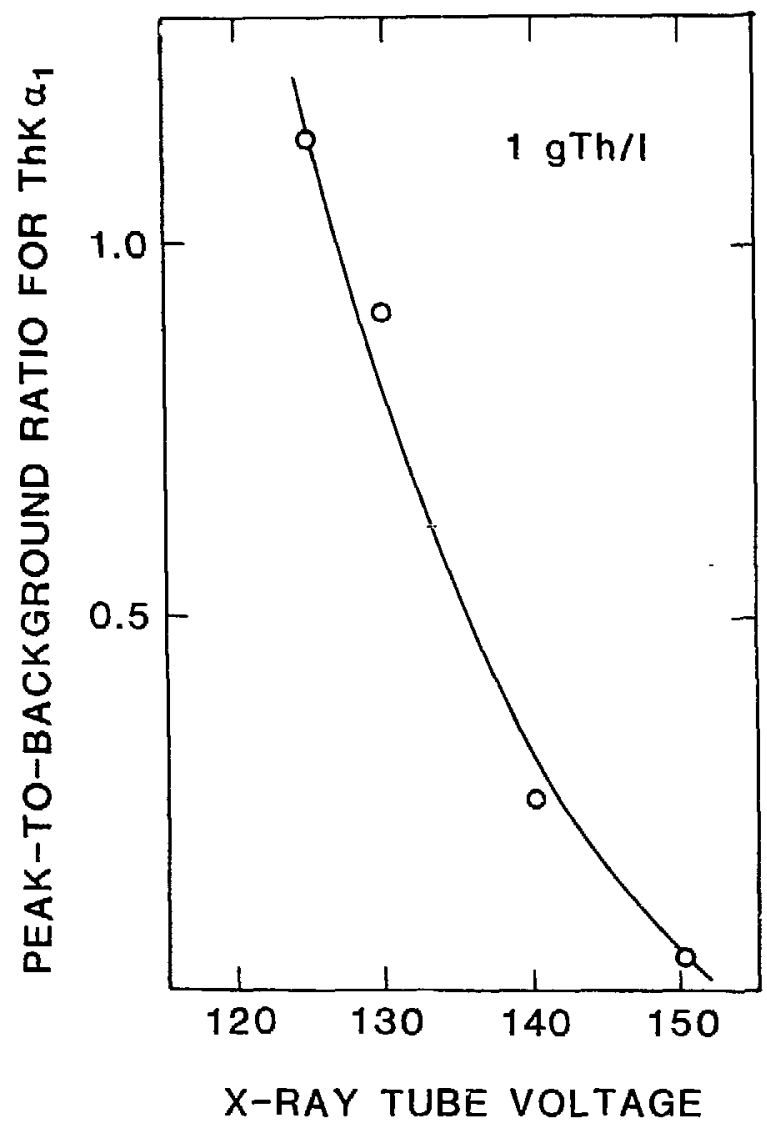

Fig. 7. Peak-to-background ratio for the thorium $\mathrm{Ka}_{1}$ line.

TABLE III

PRECISION AND PEAK AREA OF Th/Pua DETERMINATION BY XRF IN $1000 \mathrm{~s}$

\begin{tabular}{|c|c|c|c|c|}
\hline \multicolumn{2}{|c|}{ X-Ray Tube } & \multirow{2}{*}{$\begin{array}{c}\text { Counting } \\
\text { Rate } \\
\text { (counts } / 5 \text { ) }\end{array}$} & \multirow[b]{2}{*}{ Th $K \alpha_{1} / P u K \alpha_{2}$ Ratio } & \multirow[b]{2}{*}{$\begin{array}{c}\text { Precision } \\
(\%)\end{array}$} \\
\hline $\begin{array}{c}\text { Vol tage } \\
\text { (kV) }\end{array}$ & $\begin{array}{c}\text { Current } \\
(m A)\end{array}$ & & & \\
\hline 125 & 19 & 14000 & 0.512 & 1.10 \\
\hline 130 & 19 & 19000 & 0.1733 & 0.95 \\
\hline 140 & 19 & 30000 & 0.0851 & 1.29 \\
\hline 150 & 15 & 36000 & 0.0686 & 1.51 \\
\hline
\end{tabular}

a $1 \mathrm{~g} / \mathrm{l}$ thorium; $50 \mathrm{~g} / \mathrm{l}$ plutonium. 


\section{B. Performance Evaluation}

Only two accelerating voltages, 125 and $130 \mathrm{kV}$, were used. Data were collected for samples 4 through 11 . For each of the samples, three 1000-s XRF assays were made at $125 \mathrm{kV}$ and then the assays were repeated at $130 \mathrm{kV}$. Final1y, three 1000-s K-edge densitometry assays were made at $150 \mathrm{kV}$. The results are summarized in Table IV. A word of explanation is needed on the data stated in the table. The measured Th/Pu ratio is the mean of the three assays; the precision stated is due to the counting statistics from a single assay. The plutonium concentration is measured by means of the K-edge densitometry tech-nique; the precision stated is the standard devision of the the dy ays.

As shown in the table, the determination of plutonium concentration is quite good. The K-edge densitometry technique is both precise and accurate for plutonium concentrations from 50 to $220 \mathrm{~g} / \mathrm{l}$. The key then is how well one can measure the Th/Pu ratio. Figure 8 shows the measured thorium $\mathrm{K}_{1} / \mathrm{p}$ plutonium $\mathrm{Ka}_{2}$ ratio as a function of the known Th/Pu ratio. With one exception, the data points fall on a straight 1 ine.

TABLE IV

MEASUREMENT OF THORIUM-PLUTONIUM MIXED SAMPLES

\begin{tabular}{|c|c|c|c|c|c|c|c|c|}
\hline Sample & $\begin{array}{l}\mathrm{Pu} \\
(\mathrm{g} / \ell)\end{array}$ & $\begin{array}{l}\text { Th } \\
(\mathrm{g} / \mathrm{l})\end{array}$ & $\begin{array}{l}\text { Known } \\
\text { Th/Pu } \\
\text { Ratio } \\
\end{array}$ & \multicolumn{4}{|c|}{$\begin{array}{c}\text { Measured Th } \mathrm{K} \alpha_{1} / \mathrm{Pu} \mathrm{K}_{2} \\
\text { Ratio ( } \pm \text { Precision) }\end{array}$} & $\begin{array}{c}\text { Measured } \\
\text { Pu Concentration }(\mathrm{g} / \mathrm{l}) \\
\frac{(\% \text { Precision })}{(\%}\end{array}$ \\
\hline 4 & 100 & 0.5 & 0.005 & 0.155 & $(2.6)$ & 0.046 & $(2.4)$ & $100.23(0.27)$ \\
\hline 5 & 100 & 2.0 & 0.02 & 0.615 & $(0.9)$ & 0.188 & $(0.6)$ & $99.83(0.17)$ \\
\hline 6 & 100 & 0.1 & 0.001 & 0.031 & $(18.0)$ & 0.009 & $(16.0)$ & $99.55(0.40)$ \\
\hline 7 & 220 & 0.23 & 0.001 & 0.031 & $(8.6)$ & 0.010 & $(7.6)$ & $221.84(0.13)$ \\
\hline 8 & 220 & 1.2 & 0.0055 & 0.181 & $(1.6)$ & 0.055 & $(1.3)$ & $220.38(0.14)$ \\
\hline 9 & 50 & 1.0 & 0.02 & 0.512 & $(1.3)$ & 0.173 & $(1.0)$ & $50.17(1.04)$ \\
\hline 10 & 50 & 0.25 & 0.005 & 0.143 & (4.3) & 0.044 & $(3.7)$ & $50.31 \quad(0.71)$ \\
\hline 11 & 50 & 0.05 & 0.001 & 0.032 & $(39.0)$ & 0.010 & $(36.0)$ & $50.10(0.84)$ \\
\hline
\end{tabular}




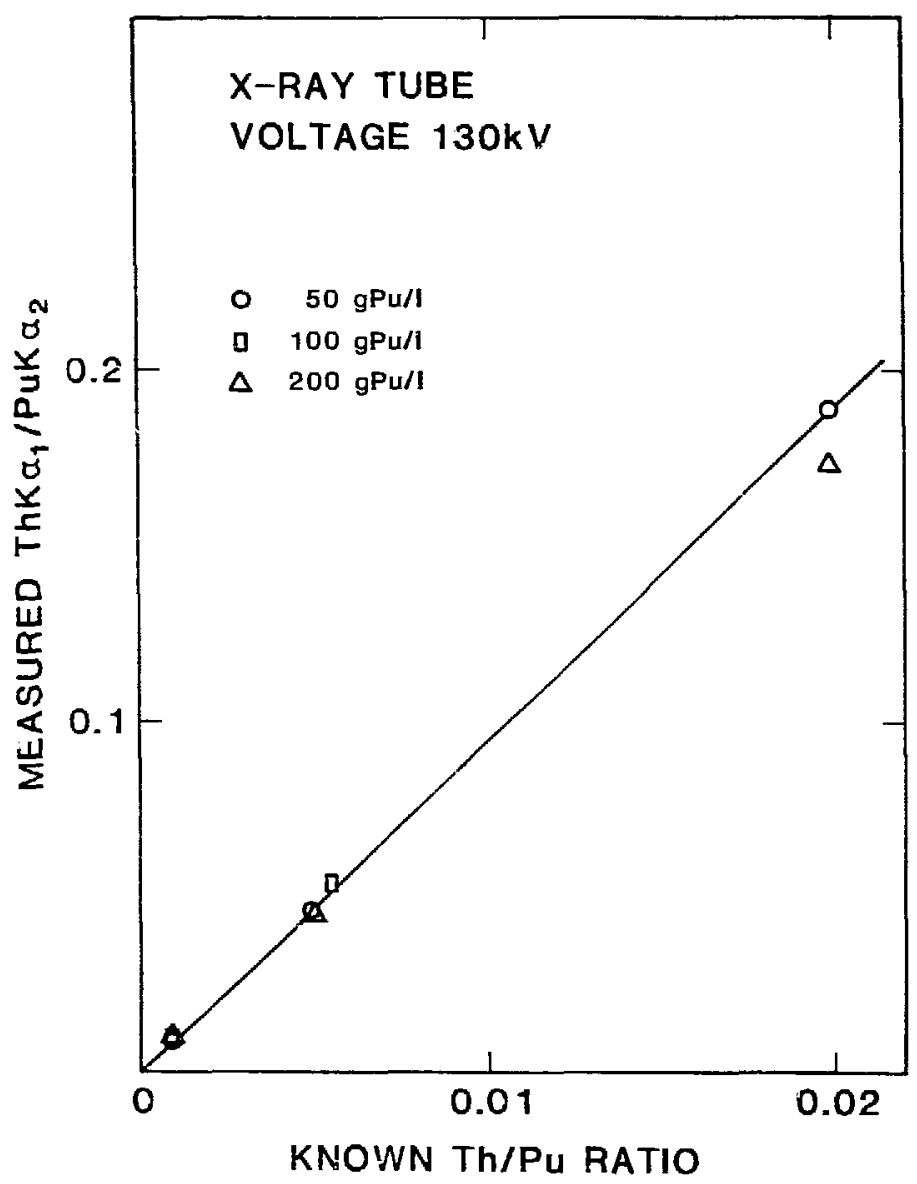

Fig. 8. Measured thorium $\mathrm{K}_{\alpha} / \mathrm{plutonium} \mathrm{K}_{2}$ ratio as function of known Th/Pu ratio.

Figure 9 shows the precision of measuring the Th/Fu ratio as a function of the thorium concentration for $1000 \mathrm{~s}$. The 130-kV accelerating voltage offers better precision in all concentrations. The precision values given in Fig. 9 and Table IV are based on trtal detector counting rates of 14000 counts/s at $125 \mathrm{kV}$ and 19000 counts/s at $130 \mathrm{kV}$. With the use of slightly larger sample volumes and less collimation, these counting rates can be increased by a factor of $:$ to 3 , thereby improving the measurement precision by $a$ factor of about 1.5 


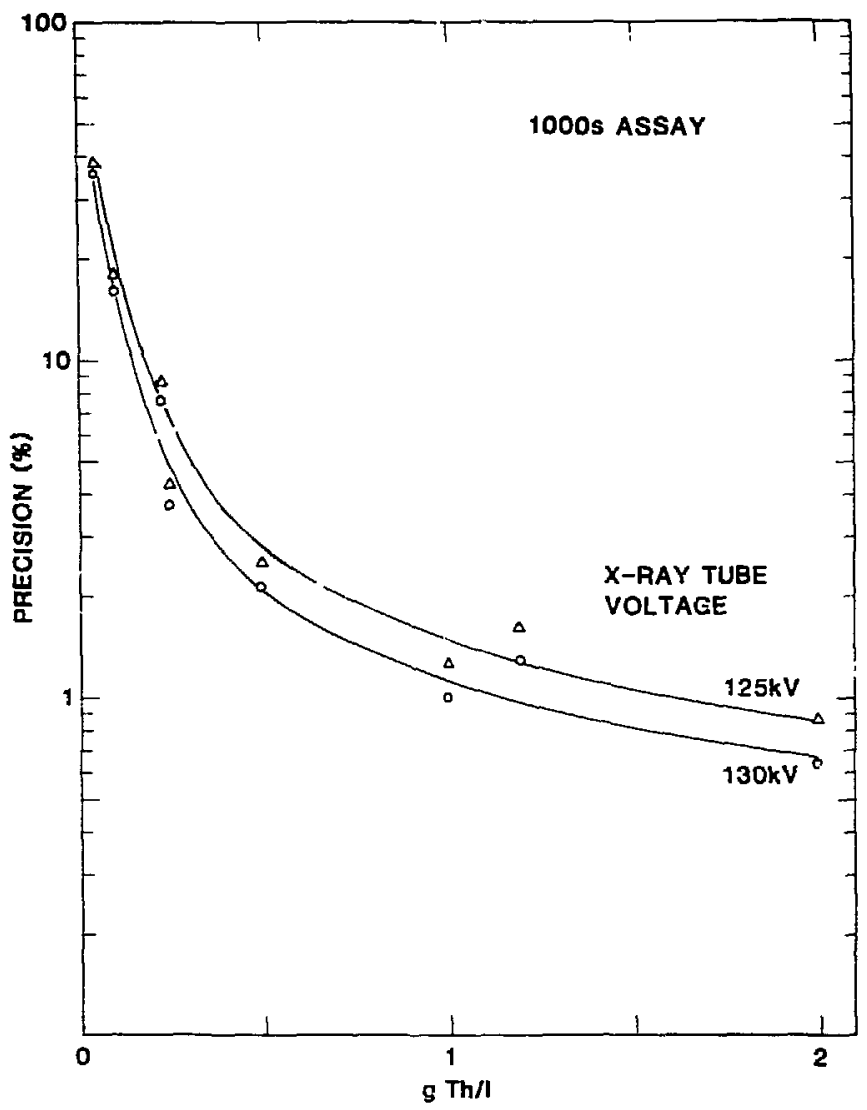

Fig. 9. The precision of measuring the Th/Pu ratio for a 1000-s assay by means of the XRF portion of the hybrid system.

IV. CONCLUSIONS

Several conclusions can be made from this feasibility study on applying the hybrid instrument for thorium-plutonium mixed solutions.

1. The optimal accelerating voltage for measuring the Th/Pu ratio is about $130 \mathrm{kV}$. This voltage offers the best peak-to-background ratio and the best measurement precision. However, a two-pass assay is required--one for XRF and one for densitometry. A compromise would use a voltage of $135 \mathrm{kV}$ for both XRF and densitometry.

2. At optimum operating conditions, the detection limit $(P=3 B$ ) for thorium is about $25 \mathrm{mg} / \mathrm{\ell}$ for a $1000-5$ assay. 
3. The minimum Th/Pu ratio that can be assayed by the hybrid instrument with reasonable precision is about $1 / 1000$. At this ratio, a precision of $5 \%$ can be achieved for a 1000-s assay of thorium concentrations greater than about $0.2 \mathrm{~g} / \mathrm{l}$.

\section{REFERENCES}

1. H. Ottmar, "An Advanced Nondestructive Assay System for Reliable and Timely Nuclear Materials Accountancy in Reprocessing," ESARDA Bulletin No. 4 (1983), p. 19.

2. H. Ottmar, H. Eberle, P. Matussek, and I. Michel-Piper, "How to Simplify the Analytics for Input-Output Accountability Measurements in a Reprocessing Plant," Report KfK 4012 (1986).

3. H. Ottmar, H. Eberle, and L. Koch, "Demonstration of NDA Technology for Reprocessing Input Analytical Measurements," presented at the 27 th Annual Meeting of the Inst. of Nucl. Materials Management (INMM), New Orleans, Locisiana, June 22-25, 1986.

4. Y. Kawarasaki, "A Simple Method for Generation of Background-Free Gamma-Ray Spectra," Nucl. Instrum. Methods 133, 335 (1979). 